\title{
The Concept of Capability Approach and Its Implications Strengthening the Humanity of (not only) Social Work Karel Řezáč
}

\begin{abstract}
In today's world we are increasingly confronted with the idea that success is expressed in numbers and material wealth. Deeper human values are somehow losing significance and prestige. The risks of such a situation are obvious at first sight. Those who are not economically productive can be seen as a burden in the process of pursuing economic prosperity. This economisation, seen from the perspective of social work, carries the dangerous situation where the social environment is deprived of responsibility for the care of social equality and justice. The capability approach is a concept that draws attention to these risks and offers a humanity concept of well-being (as an alternative to the current technicist concept). For this reason, this concept is presented in this article and its interdisciplinary use is demonstrated in the example of social work which, given its objective, should be the leading field highlighting emerging inequalities in society.
\end{abstract}

Keywords: capability approach, social work, humanity, technicity, quality of life, welfare, human development

\section{Introduction}

This article provides a critical insight into the tendencies of contemporary society which favour a technicist approach to welfare over a humanitarian one. The text is conceived as a theoretical study dealing with aspects of this state of society. The aim of the study is to outline the possibilities of using the concept of capability approach and its implications within the theory of social work. The first part offers a theoretical basis for the abovementioned state of society which is based on two opposing dimensions of the social world in the form of humanity and technicity. These two dimensions and their imbalanced state places increased demands on individuals in contemporary society, that is, it makes them increasingly responsible for the quality of their own lives. The next part presents the concept of capability approach in two interrelated concepts as a potential way to strengthen the humanity of society. In the last part I deal with the implications (i.e., derived conclusions from this concept). The question is how to use them in social work as it is a field which, according to its aim, should at least support the humanity of society and ensure quality of life for those who are not able to do it by themselves. 


\section{Humanity versus Technicity}

In ourselves and in the world around us, we encounter duality which divides many aspects of life into categories of humanity and technicity. Humanity is a summary of spiritual norms and a practical way of acting that makes man human. ${ }^{1}$ According to Blackburn, it is even a principle that influences our interpretation of the world. One tends to maximise the concept of the world which perceives subjects as humanly thinking rather than mere things. ${ }^{2}$ The concept of humanity thus represents the essence that makes man a human being. It urges us to think about the world in an empathetic way, to imagine ourselves and experience ourselves among others and in their position and at the same time to behave in this way. Technicity, on the other hand, represents the technological capacity to be countable and understandable. Technicity through nature and historical development is produced by human beings themselves, and leads to computable feasibility, representing machinations that enhance productivity. Thus, technicity is based on the past and is related to the decline in those aspects that we usually perceive as the domain of humanity. On the contrary, it highlights the technical side of things in order to achieve material productivity. ${ }^{3}$ Too much emphasis on technicity and the frantic uncovering of the exact truth can lead to the neglect of being itself. It is the way how technicity tries to dominate being. ${ }^{4}$ On one side, there is rationality, materialism, and logic. On the other, there is the opposition - emotions, spirituality, and creativity. According to the famous folk misinterpretation, we find a similar division in the human brain. This persisting myth most likely stems from the lay concept of the work of neuroscientist Roger W. Sperry. In his studies, he discovered differences in the hemispheres of the human brain and stated that the left hemisphere controls many aspects of language and logic while the right hemisphere processes spatial information and visual understanding. ${ }^{5}$ Although it turned out later that the functions of the human brain are much more complex and therefore cannot be strictly divided into two simple categories pertaining to a hemisphere with a certain general property, this discovery has caused a rise of the misconception that the hemispheres of the human brain are divided in the spirit of duality, that is, humanity versus technicity. Paradoxically, later studies have come to a result that collaboration and interconnection are important for both parts of the brain, either in logical tasks or in experiencing emotions. ${ }^{6}$ However, the fact that folk 'creativity' has given importance to brain division conveniently reflects the duality existing in each of us. The duality that can create contradictions made of unrelated words such as reason - emotion, logic - intuition, or, for example, reasoning - imagination.

However, the duality of humanity and technicity can also be found at higher levels of human life, that is, at the level of groups and communities, such as scientific disciplines, jobs, political parties, etc. This duality seems to cover a plethora of levels of our lives and create two contradictory components of human being. Of course, once one of these instances, humanity or technicity, takes precedence over the other, we can experience extreme inequalities. On the one hand, it could be the uncontrollable tools of technicist rationality in confrontation with neglected tension

Miloslav PETRUSEK, Velký sociologický slovnik, Praha: Karolinum, 1996, p. 391.

Simon BLACKBURN, The Oxford Dictionary of Philosophy, Oxford: Oxford University Press, 2016, p. 171.

Martin HEIDEGGER, Mindfulness, London: Continuum, 2006, pp. 151-155.

Jiří OLŠOVSKÝ, Slovník filosofických pojmů současnosti, Praha: Vyšehrad, 2018, pp. 408-409.

Roger W. SPERRY, Hemisphere Deconnection and Unity in Conscious Awareness, American Psychologist 23/1968, pp. 723-733.

๑ Kendra CHERRY, Left Brain vs. Right Brain Dominance: The Surprising Truth. Understanding the Myth of Left and Right Brain

Dominance (on-line), available at: https://www.verywellmind.com/left-brain-vs-right-brain-2795005, updated $15^{\text {th }}$ June 2019 , cited $17^{\text {th }}$ June 2019. 
in modern times which led to the horrors and inhumanity of the Holocaust. ${ }^{7}$ On the other hand, for example, it could be humanity's popular ownership of capital - initially standing for human equality, social security, and the desire to be rid of an ideology (that was, according to Marx, represented by the ruling class) - which led to economic decline, social closure and the emergence of a communist dictatorship dependent on authoritative discourse. ${ }^{8}$ The ideal seems to be in the middle of both of these entities and arises as a result of their interaction and control, and it should function as a prevention of similar extremes to the above examples. Indeed, when we talk about the Holocaust, humanity is awakened in us in the form of sympathy for victims and compassionate humanity. In the case of criticism of socialism, the technicity is often expressed by arguments about the rationality of capitalist freedom and the economic benefits of national cooperation, and a generally critical consideration of regime is applied.

In general, social work and the helping professions are (within this division) a discipline and a profession that is principally humanistic. However, even in this seemingly unambiguous profession, humanity (especially in the form of the approach concerning helping others) may occur less in some places and be absorbed by more technical approaches to working with people. For example, Rogers's approach - Client Centred Therapy - is based on acceptance of and empathetic understanding towards the unconditionally accepted person. ${ }^{9}$ On the contrary, Musil speaks of a procedural approach related to the administrative concept of social work where the intervention of a social worker is essentially a (technically) prepared solution to the client's situation. ${ }^{10}$ According to Musil, a social worker is thus exposed to a dilemma under the pressure of the present bureaucracy. He has to decide whether to solve the client's difficulties by a procedural or situation approach. We can also perceive the procedural approach as a potential tool of control by politicians and managers over the decisions of social workers. ${ }^{11}$ Donald Schön describes this procedural level in the context of professional jobs as technical rationality. According to him, this includes the capacity of certain expertise or theoretical knowledge which is available to the practitioner. ${ }^{12}$ As an alternative, he mentions reflection-at-action. Even if it represents a certain compromise between excessive (technicist) procedurality and purely emotional (human) action, it implicitly expresses the possibility of this non-procedural and emotional approach to practice. Such behaviour is in opposition to technical rationality and represents purely practical experience and reflection upon the situation on the basis of one's own feelings which are free from professional methods and theories. ${ }^{13}$ In social work (when thought of as a humanities field), the problem arises primarily when technicity prevails over humanity. For technical disciplines, on the other hand, a greater difficulty occurs when humanity prevails over technicity. An example of such a situation is a structural engineer who does not pay attention to technical calculations during the reconstruction of a building and relies on his 'eye' as a professional, his feelings, and practical experience. If it was a reconstruction of a dog kennel, he would probably be able to afford this, but in the case of a multi-storey building, it would be a huge risk. Just as this structural engineer cannot rely solely on his own feelings, a social worker cannot focus only on procedural procedures and thus ignore the unique complex of the client's situation. However, just as humanity (in the form of the engineer's feelings and experience) can make technicist work more effective,

\footnotetext{
Zygmunt BAUMAN, Modernita a holocaust, Praha: Sociologické nakladatelství, 2010, pp. 31-66.

Michal PULLMANN, Konec experimentu. Přestavba a pád komunismu v Československu, Praha: Scriptorium, 2011, pp. 19-22.

Oldřich MATOUŠEK, Encyklopedie sociální práce, Praha: Portál, 2013, p. 20.

0 Libor MUSIL, „Ráda bych Vám pomohla, ale... “Dilemata práce s klienty v organizacích, Brno: Marek Zeman, 2004, p. 110.

1 Ibid., pp. 110-111.

12 Donald SCHÖN, The Reflective Practitioner: How professionals think in action, London: Temple Smith, 1983, pp. 21-49.

13 Ibid., pp. 49-69.
} 
technicist procedures can improve the performance of the social worker's humanitarian work. The obvious reason why social work cannot escape the pressure of bureaucracy is because it relies itself on society, or (respectively) social solidarity. ${ }^{14}$ Of course, the degree of social solidarity is not constant as it adapts and changes with time. Indeed, each age has its own interpretations of social good and well-being. These are then the ideal for organising activities that respond to the social problems in society in a certain period. ${ }^{15}$ Without these ideals, the activity of a social worker would have no direction. It would lack the idea of a healthy social functioning, that is, the interaction between the demands of the social environment and the ability of a person to cope with them. The imbalance of these interactions is then the subject of social work. Support for social functioning is perceived as one of the main goals of social work going beyond the dimension of approach or conception of this profession. ${ }^{16}$ Just as the ideals of social goodness are changing, so are the demands of the social environment and hence the demands of social work.

The evolution of the concept of social good in our history is truly varied and diverse. For Marx, the social good was the folk ownership of capital; for Hobbes, it was the idea of an absolutist state; and for Stirner, it was individualistic anarchism. But what is the idea of today's world? Today we are dazzled by the idea of progress. ${ }^{17}$ Moreover, as many economists believe, this progress should be measured in terms of growth in society's gross domestic product. Thus, economic development in contemporary society has taken the place of the declared goal, or even the realised sense of life of an individual and society as a whole. In this context, Samuelson and Nordhaus aptly speak of the fact that each age has its own illusions. In their opinion, the belief in the power of economic well-being and prosperity represents the current illusion. ${ }^{18}$ Society seems to be neglecting the values of humanity and the duality is leaning towards the material values of technicity on imaginary scales. However, some experts denounce this feature of today's society through criticism of political decisions. For example, Braber points out that the focus of current policy on economic growth ignores circumstances that have a direct impact on the population. As an example, he mentions the interventions which were used in order to tackle the economic crisis. The efforts were focused on rescuing economic growth and the financial market, but they completely ignored impacts such as the youth unemployment rate. This one was as high as $60 \%$ in some regions as a result of the crisis. ${ }^{19}$ A potential way out of such a situation may be to emphasise the use of human development-oriented approaches, ${ }^{20}$ that is, an approach that emphasises the value of humanity. Capability approach is a universal approach with a wide application for various societal dimensions.

In the context of the perspective of social work, 'economisation' is reflected in the emphasis on the performance and efficiency of an individual. ${ }^{21}$ This then partially denies the approach to the client as a human being in the environment, thereby denying the psycho-social duality of his existence as well. The role of the environment is excluded from the complexity of the client's situation. As a result, an individual becomes responsible for his life. However, social work cannot afford such an approach, and should look for ways to balance technicity by increasing the emphasis on humanity. A possible way of achieving this state may be the usage of the capability approach. Its

14 Oldřich MATOUŠEK, Základy sociální práce, Praha: Portál, 2007, p. 10.

15 Ibid., p. 83.

16 Pavel NAVRÁTIL, Reflexivní posouzení v sociální práci s rodinami, Brno: MUNI PRESS, 2014, pp. 50-51.

17 Tomáš SEDLÁČEK, Ekonomie dobra a zla, Praha: 65. Pole, 2012, p. 28.

18 Paul A. SAMUELSON and William D. NORDHAUS, Economics, University Park, PA: Pennsylvania State University Press, 2001 , p. 81.

19 Collin den BRABER, The introduction of the capability approach in social work across a neoliberal Europe, Journal of Social Intervention: Theory and Practice 4/2013, p. 64.

20 Ibid.

21 Markéta ELICHOVÁ, Sociální práce: Aktuální otázky, Praha: Grada, 2017, p. 18. 
principle does not neglect the importance of the contextual conditions of a human being and, on the contrary, places them at the forefront. The lack of attention to the importance of the environment in the context of the trend of the capability approach across science disciplines initiates the idea of using this concept also within the framework of social work theory in order to increase the emphasis on the humanity of social work and hence of society as a whole. This idea works against the profit-oriented economised tendencies of today. Efforts to link the capability approach and social work have been made, for example, by Slabbert. In her study, she points out the explicit usability of the approach in assessing client welfare. The application of the approach was carried out in research by social work students who, through the concept of capability approach, were able to detect aspects causing client discomfort based on the presented case reports. The author of the study therefore recommends the use of the capability approach in social work and also the inclusion of this approach in social work study programmes in order to strengthen the potential of practical skills of future social workers. ${ }^{22}$ In the field of social work research, for example, Nkhoma and Charnley use the capability approach as a framework for qualitative research enabling a comprehensive disclosure of a wide range of different aspects of child prostitution. ${ }^{23}$ Interconnection thus seems to be not only a possible but also a suitable way of supplementing social work.

\section{Two Views of the Capabillity Approach}

Although the indisputable author of the capability approach is the Indian economist and philosopher Amartya Sen, who even received the Nobel Prize in economics in 1998 for it, this concept is so revolutionary that it has received further elaboration. The work of Martha Nussbaum is worth mentioning in this context. She transformed the original rather abstract concept into a more concrete form. It seems as if the duality (mentioned in the first chapter) persists here as well. Although we are increasingly approaching the humanitarian mindset, even the capability approach as a purely humanitarian approach to welfare has two concepts. One is more abstract and the other more tangible. Thus again (albeit to a small extent), there is an imaginary division of the dimensions of humanity and technicity. For this reason, I consider it appropriate to devote space to both of these concepts separately and not to insist on their unconditional interconnection into a single complex. However, the hierarchy is clear in this respect, since Nussbaum explicitly follows the concept of Sen. The introduction of the principle of the capability approach according to Sen is included in the immediately following chapter. In the next chapter then, there is an outline of the Nussbaum's concept.

\section{The Concept of Amartya Sen}

Sen's concept of capability approach is based primarily on the criticism and revision of John Rawls' ideas and utilitarianism. ${ }^{24}$ Utilitarianism is an ethical theory. Its central category is utility. According to utilitarianism, the moral criterion of action is its usefulness in creating happiness. This means that ethical meaning is not a motive or intention but an act and its outcome. The aim is then the common good for all expressed by the formula the greatest happiness for the

22 Ilze SLABBERT, Applying the capability approach in social work education, Social Work Education 7/2018, pp. 867-880.

23 Pearson NKHOMA and Helen CHARNLEY, Child protection and social inequality: understanding child prostitution in Malawi, Social sciences 10/2018, p. 185.

24 Amartya SEN, Equality of What?, The Tanner Lecture on Human Values, Delivered at Standford University, 22 ${ }^{\text {nd }}$ May 1979, Oxford: Oxford University Press, 1980, pp. 198-216. 
most people. ${ }^{25}$ On the basis of utilitarianism, society can be defined as just if its rules support the achievement of the maximum sum of the benefits for society (consisting of individuals and their benefits). The problem is that justice in society is derived only from the overall benefit which leads to a lack of interest in its even redistribution among the members of society. In such circumstances, there may be a restriction of some for the benefit of others in the name of the total amount of social benefit and its increase, and, at the same time, a different division of rights and obligations. ${ }^{26}$ According to Sen, this theory of justice does not provide an analysis of living conditions that should be seen as a basic concept. The perspective of this concept is too narrowly focused and thus excludes the evaluation of many other important aspects. On the contrary, Sen highlights human individuality and diversity, which is reflected in no less varied individual needs. So we will not achieve the same level of well-being if we meet the needs of two people in the same way. ${ }^{27}$ Sen sees the cause of these difficulties, among other things, in the conflict of the roles of human beings who are recipients of progress but, at the same time, also a means of achieving it. This dual role causes confusion in goals and resources in the process of planning and policy making which often focuses on production and prosperity. This is considered the essence of people-driven progress. It is omitted though that the ultimate value should be the people themselves and their quality of life. The acquisition of production and prosperity, on the contrary, is simply a means of achieving such a quality of life. ${ }^{28}$

Thus, the focal point of the development process is the aspect of freedom rather than economic indicators. This is due to the fact that the assessment of progress must be assessed primarily in terms of the dimension of strengthening the freedom that people have and also because the achievement of development is dependent on the free action of people. ${ }^{29}$ Sen further divides freedom into five categories of instrumental freedoms: (1) political freedoms, (2) economic opportunities, (3) social opportunities, (4) guarantees of transparency, and (5) assurance of protection. Each of these different types of rights and opportunities helps to develop the human potential in a general sense. ${ }^{30}$ Furthermore, to understand the whole concept of capability approach, it is necessary to distinguish two key elements in Sen's theory. It is a functioning and the already mentioned potentiality (in the original it is the term capability). The functioning can be understood as diverse states of being and activities. These states should be distinguished from the commodities and resources that are the means to achieve them (for example, cycling and bike ownership). These are different activities, states, or situations that people spontaneously consider important and shape the human personality. Because people have different values and experiences, there is no fixed hierarchy in the process of functioning. The functions achieved are measurable, observable, and comparable. These are, for example, literacy, life expectancy, health, sports activities, etc. ${ }^{31}$ Functioning is essentially the goal of human life but it can also be a means of achieving a higher goal. It may be easier, such as avoiding illness and death or dieting, or it may be more complex, such as self-esteem, participation in society, or the ability to speak in public without feeling ashamed. The functioning may also be general, such as dietary precautions, or may be specific, such as the possibility of consuming a favourite meal.

\footnotetext{
PETRUSEK, Velký..., p. 1361.

SEN, Equality ..., pp. 198-199.

Amartya SEN, Inequality Re-examined, Oxford: Clarendon Press, 1992, pp. 81-87.

8 Amartya SEN, Development as Capability Expansion, in: Readings in Human Development, ed. Sakiko FUKUDA-PARR and A. K. Shiva KUMAR, New Delhi and New York: Oxford University Press, 2003, p. 41.

9 Amartya SEN, Development as Freedom, New York: Knopf, 1999, p. 4.

0 Ibid., p. 10.

31 SEN, Development as Capability..., pp. 43-44.
} 
The second term, being potentiality, can be understood (in the singular) as the general level of human being, that is to say, a specific trait of a person which is different for everyone and simply represents the sum of how we can live a free life. At the same time, however, the term can be seen in the plural where individual potentialities belong to more specifically formulated freedom which is focused more closely on some aspect of human life (finance, human relations, security, etc.). Potentialities include the real opportunities which people have in their lives. Potentiality in Sen's concept represents freedom of choice. One can choose from a set of alternative lives that people want to live. ${ }^{32}$ Perhaps the most commonly used definition of potentiality is: 'the various combinations of functionings that a person can achieve, ${ }^{33}$ or also 'a set of vectors of functionings, reflecting the person's freedom to lead one type of life or another. ${ }^{34}$ Both of these definitions are based on the original theory of Amartya Sen. He himself has defined potentialities as a set of valuable functions which can be considered as valuable and which one can effectively access. ${ }^{35}$ They therefore represent the true freedom of the individual. One can choose between different combinations of functioning, or to choose his own path in life. In addition to the degree of individual freedom as a guarantee of human development, we must also mention the element of choice which is also an essential part of the whole concept. According to Sen, freedom of choice is, in fact, implicitly conditioned by a two-way relationship between people's participation in their development and public policy that takes into account the importance of potentiality. ${ }^{36}$

In summary, the concept of capability approach seeks to organise a society that does not assess the level of development based on technicist economic indicators. It focuses, in this respect, on humanistic indicators of human potential and quality of life. Such quality is then conditioned by the real opportunity to live the life that an individual wants. Members of such a society have the possibility to make free choices as there are enough potentialities, that is, real opportunities to achieve functioning according to their own individual determination. It should also be noted that Amartya Sen is sometimes criticised for his concept. Some people object that it is too general and that Sen does not offer examples of practical use of the capability approach in practice. ${ }^{37}$ However, it should also be pointed out that (thanks to its character) this concept is also very variable and has found its interdisciplinary application in a whole spectrum of other areas, especially in the social sciences. ${ }^{38}$ Martha Nussbaum, mentioned above, offers one of the most significant elaborations that very explicitly follows Sen's ideas. In the context of human rights, she focused on the concretisation of individual main human potentialities.

\section{The concept of Martha Nussbaum}

The important contribution of the American philosopher Martha Nussbaum to the concept of capability approach lies mainly in the fact that she compiled a universal list of ten major human potentialities. Her work is based on the thoughts of Amartya Sen. Thus, the whole concept is modified from the original instrument of welfare measurement to a more specific normative

BRABER, The introduction..., pp. 67-68.

33 Sabina ALKIRE and Séverine DENEULIN, The Human Development and Capability Approach, in: An introduction to the Human development and Capability Approach, ed. Séverine DENEULIN and Lila SHAHANI, London: Earthscan, 2009, p. 31.

34 Sabina ALKIRE, Why the capability approach?, Journal of Human Development 6/2005, p. 121.

35 SEN, Development as Freedom..., p. 18.

36 Ibid.

37 Martin EHL, Rozvojové země a trh trochu jinak, Mezinárodní vztahy 1/2000, p. 108.

38 ○ Ingrid ROBEYNS, The Capability Approach (on-line), available at: https://plato.stanford.edu/entries/capability-approach, updated $3^{\text {rd }}$ October 2016, cited $28^{\text {th }}$ June 2019. 
framework which should be an enforceable part of the legislation of all states as these are indispensable conditions of human dignity. ${ }^{39}$ These main potentialities must be ensured in society at least to a minimum degree to each of its members. If not, society does not fulfil the value of social justice. ${ }^{40}$ The author thus (with the perspective of the duality, i.e., humanity versus technicity) combines both dimensions by carrying out a technicist application of humanities and of their outcomes.

A concrete list of the main human potentialities is as follows: (1) life - the possibility of living a valuable human life at its normal length, avoiding the risk of premature death and life deprivation; (2) physical health - good health opportunities, including reproductive health, adequate nutrition, care, and shelter; (3) physical integrity - the ability to move freely from place to place, protection against violent assault, including sexual assault and domestic violence, sexual satisfaction opportunities, and reproductive choices; (4) sense, imagination, and thinking - the ability to use senses, imagination, thinking, and reason, and the ability to do these activities in a 'truly human' way, an informed and cultivated way ensured by accessible and adequate education, the ability to use creative imagination freely within spirituality and art, the ability to use one's mind in ways which contain the ensured freedom of expression with respect to political and artistic expression and freedom of religion, enjoyable experiences, avoiding discomfort and pain; (5) emotions - the possibility of having an emotional attachment to things and surrounding people, to love those who love and care for us, to miss them, to love, to mourn, to experience desire, gratitude, and justified anger in a general sense, to avoid development that is accompanied by fear and anxiety; (6) practical thinking - the ability to formulate certain concepts of goodness and engage in critical thinking about the planning of one's own life (which implies the protection of freedom of conscience and religious customs); (7) relationships - (a) the ability to live with and in relation to others, to recognise and express interest in other human beings, to engage in various forms of social interaction, to be capable of compassion and empathy, and (b) to have a social framework for self-esteem and not to be humiliated, to be considered as a dignified being of equal value to others, not to be discriminated against on the basis of race, sex, sexual orientation, ethnicity, caste, religion, or nationality; (8) other species - to be able to live with an interest in and relationship with animals, plants, and the world of nature; (9) play - be able to laugh, play, and enjoy leisure activities; and (10) control of one's environment - (a) political, being the ability to participate effectively in the political decisions that govern human life, have the right to political participation, to protect freedom of expression and association, and (b) material, having the ability to own property (movable and immovable), to possess property rights to the same extent as others, to have the right to seek employment on the principle of equality with others, and to be protected from unauthorised persecution and the deprivation of property. ${ }^{41}$ These are therefore the basic human potentialities, or capabilities, abilities, possibilities, etc., which should be available for all members of society if this society is to be recognised as socially fair.

\section{Use of Capability Approach in Social Work}

Thanks to their value background and applied principles, the theoretical bases of the capability approach are also applicable to the theory of social work and the helping professions. In the

39 Martha NUSSBAUM, Women and Human Development, New York: Cambridge University Press, 2000, pp. 5-13.

40 Martha NUSSBAUM, Capabilities as Fundamental Entitlements: Sen and Social Justice, Feminist Economics 9/2003, pp. 41-42.

41 Martha NUSSBAUM, Creating Capabilties: The Human Development Approach, Cambridge, MA: Harvard University Press, 2011, pp. $33-34$. 
present conception of human well-being as well as social work and other related fields, the concept of social functioning has a key position. ${ }^{42}$ This term can be seen as a common basis in defining the quality of life. According to Navrátil and Musil, social functioning is the key to understanding the specific approach of social work. ${ }^{43}$ The use of the term social functioning has already exceeded the boundaries of a particular theoretical school or a specific model of social work. The support of social functioning has also begun to be seen as one of the main objectives of social work as a specific profession. ${ }^{44}$ It indicates people's ability to cope with the expectations of the social environment. According to this perspective, people are in constant interaction with the environment. Normally, the interaction is in balance. If people do not adequately manage environmental requirements, balance is unstable and a problem arises. ${ }^{45}$ This imbalance is the space for social work intervention which can either seek to strengthen the social functioning of the client, regulate the expectations of the environment, or strengthen interaction.

The intervention targeting, in this sense, is largely based on the chosen approach of social work. Based on Payne's theory, Navrátil differentiates these approaches into three basic paradigms, later called typical approaches of social workers. These are: (1) the therapeutic approach, (2) the counselling approach, and (3) the reform approach. ${ }^{46}$ The advantage of these paradigms is that they generalise a wide range of different approaches to social work into three categories which, within this triple division, associate the most important common features and the core principle of these approaches. The disadvantage of this model and its usage, however, can be precisely the generalisation that distracts one from the particular and detailed specifics of the individual approaches. Thus, it prevents complete universality. Each of these general approaches, respectively the social worker acting according to it, ensures balance from a different perspective. The therapeutic approach focuses on mental health and well-being as a prerequisite for healthy social functioning, the counselling approach focuses on problem-solving and access to relevant information and services, and the reform approach focuses on social equality in various dimensions of social life. ${ }^{47}$ The concept of practice differs from one approach to another along with a different discourse. The discourse can be interpreted as a principle and a socially accepted norm for shaping the meaning of a message in a particular use, i.e., a message with an attribute. ${ }^{48}$ In the case of the therapeutic approach, it is the area of psychological discourse; in the counselling approach, it is about the legal discourse; and the reform approach focuses on political discourse. The form of intervention subsequently differs with the chosen approach and discourse and the course of action of social workers is, of course, different. The model can also be extended to levels of social work: (1) micro, (2) mezzo, and (3) macro. The term micro practice refers to activities that help solve problems of individuals. We include social work with families and groups in the mezzo level, and the macro practice focuses on improving social conditions and changes throughout society. It therefore includes activities such as political events, community planning, public education events, etc. ${ }^{49}$ Generally speaking, the therapeutic approach applies mainly to the micro practice of social work, the counselling approach to mezzo practice, and the reform approach primarily to the macro

\footnotetext{
2 Zuzana PALOVIČOVÁ, K pojmu sociálneho fungovanie, FILOZOFIA 9/2011, p. 833.

43 Pavel NAVRÁTIL and Libor MUSIL, Sociální práce s př́slušníky menšinových skupin, in: Sborník prací fakulty sociálních studií brněnské univerzity, Sociální studia č. 5, Brno: Fakulta sociálních studií, 2000, p. 118.

44 NAVRÁTIL, Reflexivní..., p. 50.

45 NAVRÁTIL and MUSIL, Sociální..., p. 118.

46 Ibid., p. 121.

47 Ibid., pp. 121-123.

48 Jiří KRAUS, Rétorika a řečová kultura, Praha: Karolinum, 2010, p. 18.

49 Cindy GARTHWAIT, Dictionary of Social Work, Missoula: The University of Montana, 2012, p. 12.
} 
practice of social work. In this way, a broad spectrum of social work activities can be theoretically described.

The implications of the capability approach are primarily related to the concept of expectation. In terms of psychology, the concept of expectation can be differentiated into two different forms. In English, we can also see the difference from a linguistic point of view, as the Czech word očekávání can be translated as expectation, but at the same time, in a slightly different sense, it could be translated as expectancy. The first expression (expectation) represents an assumption or a feeling or prediction based mainly on human experience. In the case of the term expectancy, the assumptions are not based on experience but rather on intuition relying on faith and hope that the future will be according to one's wishes. The nature of this expectation is positive and one could say innovative as it brings the specific information about personal expectation, i.e., according to one's idea. ${ }^{50}$ For the sake of clarity, I will give an example revealing this ambiguity of the Czech language. If one is asked at a job interview, 'Jaká jsou vaše očekávání od pracovní pozice, o kterou se ucházite?' ('What are your expectations concerning the job position you are applying for?'), there could be two interpretations of such a question. If one understood the Czech term očekávání in the sense of expectation, he would try to prove his knowledge of the job and the future tasks, no matter whether he likes them or not. If one interpreted the word očekávání as 'expectance', he would start to talk about what he thinks about the job, that is, how the job could be useful for him, how he could be useful in the job, why he believes that this job opportunity is right for him, etc. It is through this ambiguity that one can understand how the concept of capability approach views the social interactions of man with the environment differently. While the perspective of social work treats expectation as a social construct of society (which attributes the required social functioning to certain roles), in the case of the capability approach expectation is understood as a person's idea of how his social functioning should look, that is, how he would like to fulfil his social roles. Living one's own free choice on the basis of the secured potentials that make this possible is thus a challenge for social work. Social workers should not only help clients to live the life which society expects from them but also help them to live the most acceptable life according to their own view.

Looking at social work from the perspective of the capability approach, it should be considered how individual approaches and levels of social work perceive the provision of potentialities. Simply, it can be assumed that discourses of individual approaches partially limit the social worker's outlook when finding solutions to ensure the client's potentiality. The dimension of potentialities (as an element linking the client's wishes, needs, or expectations with their real life) essentially defines the scope of social work intervention. As intervention based on the chosen social worker approach is subordinate to the appropriate discourse of the given approach, the social worker may, as a result, choose (and then mediate to the client) partially limited ways to ensure social functioning. This may be due to an excessive focus of social workers on the difficulties and solution of the situation. When the dimension of the solution accepted by the client is added, no attention is paid to other possible solutions. The expansion of social work caused by adding the ideas based on the capability approach attaches greater importance to the choice of solution, that is, to the ways of dealing with the adverse situation of the client. Thanks to this, the problem can be solved more efficiently, comprehensively, and above all with much greater interest and involvement of the client. In other

50 Cf. Mallappa BASAVANNA, Dictionary of Psychology, New Delhi: Allied Publishers, 2000, p. 139; Raymond J. CORSINI, The Dictionary of Psychology, New York: Routledge, 2016, p. 351; David MATSUMOTO, The Cambridge Dictionary of Psychology, Cambridge: Cambridge University Press, 2009, p. 193. 
words, the concept of capability approach can interconnect individual approaches of social work, as it is a prerequisite for their variable combinations. This is relevant in the process of searching for possibilities of differently oriented solutions to the client's situation.

A concrete list of human potentials can then offer a new, more comprehensive view of the client's situation to the social work field. It can help to identify the sources of the problem more easily and transparently. It thus extends the concept of assessing the client's situation known, for example, from the practice of social and legal protection of children. ${ }^{51}$ Particular potentialities represent (mainly for social policy, the reform approach, and the macro-practice of social work) a model anchoring the goal of policy direction towards social equality. It can be used for the evaluation of a part of society and its state, and for strategic planning of social services. This concept represents the direction and areas of helping needy people to achieve an adequate quality of life. Social work is again one of the tools for ensuring this quality of life for those who are not capable of doing it by themselves.

\section{Conclusion}

It may seem that the search for a way to make social work even more humanistic is unnecessary given its original value basis. However, it should be remembered that even if social work remained untouched by the trend of time to attribute value to technicist well-being (which seems at least unlikely), social workers should undoubtedly have been the first to draw attention to this social phenomenon as these social trends are the most apparent in their practice. Capability approach is clearly a concept with a very wide range of possible applications, including social work.

The approach enriches the concept of balance between the social functioning of man and the expectations of his environment with the dimension of man's own inner expectations of himself. Within the concept of typical social work approaches, the capability approach (or element of potentialities) brings an element of focus to the search for a set of possible multi-discursive and complex solutions to the client's adverse situation. Thus, it avoids inconsistencies and differences in different approaches. It allows for a more efficient, conscious, and freer solution to the client's situation through his own free choice from a range of available solutions.

In practice, social workers, acting according to the principle of capability approach, would primarily negotiate the objective of intervention together with the client by means of a dialogue creating a confrontation of the client (in his situation and role) with the expectations of the social environment. At the same time, in this dialogue they would map the expectations of the client himself, that is, how his situation should be addressed and the role fulfilled according to his wishes. Finally, the goal should be a compromise between the expectations of the environment and the expectations of the client. When seeking to achieve this goal, the social worker should, if using this approach, look for and offer alternative ways of achieving it. From these possible ways, the client would then freely choose the one he wants to take. Individual potentialities can serve as a starting point for a comprehensive assessment of the client's life situation which takes into account various contextual aspects of the client's situation. They can also be the starting point for assessing the equality of different members or groups in society and form the criterion basis for declaring their rights. Ensuring potentialities can also be used as an indicator of whether the objective of social worker intervention has been comprehensively achieved. The fulfilment of potentialities could

51 (c) MPSV ČR, Informace k vyhodnocení situace dítěte (on-line), available at: https://www.mpsv.cz/files/clanky/14230/vyhodnocovani. pdf, cited $29^{\text {th }}$ June 2019 . 
then generally define the boundary of social work, or define its goal in the form of the provision of potentialities. However, the question remains to what extent potentialities should be hedged, and in which specific case the potentiality can be identified as hedged. The capability approach can thus inspire social work to recognise the importance of the client's freedom of choice from the offered ways towards the fulfilment of society's expectations. The place for social work will then always be where the impetus for such a choice is in limitations, inequality, and injustice. Both concepts seem to have good compatibility. Social work can also be seen as a tool for balancing inequalities and for the fulfilment of unfulfilled potentials that can be identified through the capability approach as an assessment framework. But does the concept of capability approach offer such a distinct and unique way of thinking about social phenomena? Could it be firmly transformed into a method or theory of social work in the future? Although many indicators suggest such a conclusion, there is still a long way to go. At the end of such a journey, social work may be richer with an approach that supports the humanity of this profession and its clients in an innovative and new way.

\author{
Contact \\ Mgr. Karel Řezáč \\ University of West Bohemia \\ Faculty of Arts \\ Department of Sociology \\ Sedláčkova 15, 30100 Pilsen \\ rezack@kss.zcu.cz
}

